\title{
Measurement of drug concentration and bacterial contamination after diluting morphine for intrathecal administration: an experimental study
}

Aart Jan W. Teunissen ${ }^{1 *}$ (D, Mark V. Koning ${ }^{2}$, Elisabeth J. Ruijgrok ${ }^{3}$, Willem J. Liefers ${ }^{4}$, Bart de Bruijn ${ }^{1}$ and Seppe A. Koopman ${ }^{1}$

\begin{abstract}
Background: Low concentrations of morphine are required for safe dosing for intrathecal injections. Sometimes, manual dilution of morphine is performed to achieve these low concentrations, but risks dilution errors and bacterial contamination. The primary goal was to compare the concentrations of morphine and bupivacaine between four groups of syringes. The secondary goal was to investigate the difference in contamination rate between these groups.

Methods: Twenty-five experienced anesthesia providers were asked to prepare a mixture of bupivacaine $2.0 \mathrm{mg} / \mathrm{ml}$ and morphine $60 \mathrm{\mu g} / \mathrm{ml}$ using 3 different methods as clean and precise as possible. The fourth method used was the aspiration of ampoules prepared by the pharmacy. The concentrations of morphine and bupivacaine were measured by High-Pressure Liquid Chromatography (HPLC). The medication was cultured for bacterial contamination.

Results: Group 1 (median $60 \mu \mathrm{g} / \mathrm{ml}$; 95\% Cl: 59-110 $\mu \mathrm{g} / \mathrm{ml}$ ) yielded 3 outliers above $180 \mu \mathrm{g} / \mathrm{ml}$ morphine concentration. Group $2(76 \mu \mathrm{g} / \mathrm{ml} ; 95 \% \mathrm{Cl}: 72-80 \mu \mathrm{g} / \mathrm{ml})$ and $3(69 \mu \mathrm{g} / \mathrm{ml} ; 95 \% \mathrm{Cl}: 66-71 \mu \mathrm{g} / \mathrm{ml})$ were consistently higher than the target concentration of $60 \mu \mathrm{g}$. The group "pharmacy" was precise and accurate $(59 \mu \mathrm{g} / \mathrm{ml} ; 95 \% \mathrm{Cl}$ : 59-59 $\mathrm{\mu g} / \mathrm{ml})$. Group 2 and "pharmacy" had one contaminated sample with a spore-forming aerobic gram-positive rod.

Conclusion: Manually diluted morphine is at risk for deviating concentrations, which could lead to increased sideeffects. Medication produced by the hospital pharmacy was highly accurate. Furthermore, even when precautions are undertaken, contamination of the medication is a serious risk and appeared to be unrelated to the dilution process.
\end{abstract}

Keywords: Morphine, Bupivacaine, Anesthesia providers, Concentration, High-pressure liquid chromatography, Dilution, Contamination

\footnotetext{
* Correspondence: teunissena@maasstadziekenhuis.nl

${ }^{1}$ Anesthesiology, Maasstadziekenhuis, Maasstadweg 21, 3079DZ Rotterdam,

The Netherlands

Full list of author information is available at the end of the article
}

(c) The Author(s). 2020 Open Access This article is licensed under a Creative Commons Attribution 4.0 International License, which permits use, sharing, adaptation, distribution and reproduction in any medium or format, as long as you give appropriate credit to the original author(s) and the source, provide a link to the Creative Commons licence, and indicate if changes were made. The images or other third party material in this article are included in the article's Creative Commons licence, unless indicated otherwise in a credit line to the material. If material is not included in the article's Creative Commons licence and your intended use is not permitted by statutory regulation or exceeds the permitted use, you will need to obtain permission directly from the copyright holder. To view a copy of this licence, visit http://creativecommons.org/licenses/by/4.0/ The Creative Commons Public Domain Dedication waiver (http://creativecommons.org/publicdomain/zero/1.0/) applies to the data made available in this article, unless otherwise stated in a credit line to the data. 


\section{Implication statement}

This study demonstrates that manual dilution of medication leads to inaccurate concentrations. This might lead to unsafe dosing.

\section{Background}

Intrathecal administration of morphine is an effective method of analgesia. A single dose of $100-300 \mu \mathrm{g}$ produces analgesia that lasts over $24 \mathrm{~h}[1,2]$. However, adverse events due to intrathecal morphine, such as late respiratory depression and pruritus, are described to be dose dependent [3]. The risk for adverse events may increase in doses $>500 \mu \mathrm{g}$ [4-6]. Given this narrow therapeutic range, accurate dosing is paramount.

To achieve a safe dose of intrathecal morphine, low concentrations of morphine are necessary. However, commercially available concentrations of morphine in the Netherlands range up to $10 \mathrm{mg} / \mathrm{ml}$ or $20 \mathrm{mg} / \mathrm{ml}$. Some health care providers use small volumes of $10 \mathrm{mg} /$ $\mathrm{ml}$ morphine to achieve a dose of $150 \mu \mathrm{g}$, others dilute the morphine manually [7-9]. This leaves room for error with potentially fatal outcomes as a result.

In addition, precautions should be taken to prevent a contaminated injection, since the introduction of bacteria into the cerebrospinal fluid can lead to meningitis [10]. Even though the incidence of meningitis after an intrathecal injection is estimated to be 1:53.000, manipulations for manual dilution could contaminate the injectate and increase this incidence [11].

The objective of the current study is to measure precision and accuracy in dilution of morphine and bacterial contamination. Previous studies have investigated the dilution of morphine, but limited conclusions can be drawn due to their study design $[8,9]$. The methodology was non-standardized [8] and a limited number of subjects diluted the morphine [9]. This may overestimate the accuracy of clinical practice. Moreover, bacterial contamination was not measured. In this study, various experienced anesthesia providers prepared the syringes according to three standardized methods of dilution and syringes extracted from ampoules prepared by our pharmacy. We hypothesized that the number of manoeuvres increases the risk for a dilutional error and bacterial contamination.

\section{Methods}

For this experimental study, medical ethical approval was waived by the medical ethical committee of the.

Maasstad Hospital (Toetsingscommissie Wetenschappelijk Onderzoek Rotterdam e.o., February 5, 2018). The primary outcome was the precision and accuracy in morphine concentration within groups. The secondary outcome the difference in contamination rate between these groups.

Twenty-five experienced anesthesiologists and nurse anesthetists were asked to prepare a mixture of bupivacaine and morphine according to predefined methods. The characteristics of these methods are described in Table 1 . The target concentrations were $2.0 \mathrm{mg} / \mathrm{ml}$ bupivacaine and $60 \mu \mathrm{g} / \mathrm{ml}$ morphine. They were provided with medication, sterilely packed syringes and needles and aseptic measures, as written below.

\section{Medication}

For this study, commercially available medication was used for the first three methods. Specifically, bupivacaine $5 \mathrm{mg} / \mathrm{ml}(5 \mathrm{ml})$, morphine $1 \mathrm{mg} / \mathrm{ml}(1 \mathrm{ml})$ and morphine $10 \mathrm{mg} / \mathrm{ml}(1 \mathrm{ml})$. For the group Pharmacy, the hospital pharmacy provided ready-to-use (RTU) ampoules of 5 $\mathrm{ml}$, containing a combined solution of $2.5 \mathrm{mg} / \mathrm{ml}$ bupivacaine and $60 \mu \mathrm{g} / \mathrm{ml}$ morphine. The ampoules were prepared under Good Manufacturing Practice (GMP) conditions by the pharmacy that is GMP certified by the Dutch Health Care Inspectorate. In short, a batch of 50 sterile ampoules were prepared. The solution was prepared in a Grade A with Grade C background aseptic cleanroom and glass ampoules were filled under nitrogen. The fluid was filtered through a $0.22 \mu \mathrm{m}$ bacterial filter. The ampoules were sterilized in the autoclave for $15 \mathrm{~min}$ in 121 degrees Celsius. Quality control tests in a GMP accredited laboratory included sterility, fill volume, shelf-life, and concentration.

\section{Experimental design}

The participants received written and oral instructions for preparation of the syringes. It was stressed that the mixtures needed to be as clean and precise as possible. The preparation of medication was performed on the Post Anesthesia Care Unit, on a clean table, specifically

Table 1 Characteristics of dilution per method

\begin{tabular}{|c|c|c|c|}
\hline Group & Starting concentration & Number of dilutions & Dilution volume \\
\hline Method 1 & $10 \mathrm{mg} / \mathrm{ml}$ morphine & 1 & $100 \mathrm{ml} \mathrm{NaCl} 0.9 \%$ \\
\hline Method 2 & 10 mg/ml morphine & 2 & $9 \mathrm{ml} \mathrm{NaCl} 0.9 \%$, twice \\
\hline Method 3 & $1 \mathrm{mg} / \mathrm{ml}$ morphine & 1 & $9 \mathrm{ml} \mathrm{NaCl} 0.9 \%$ \\
\hline Pharmacy & $\begin{array}{l}60 \mathrm{mcg} / \mathrm{ml} \text { morphine } \\
2.5 \mathrm{mg} / \mathrm{ml} \text { bupivacaine }\end{array}$ & 0 & N/A \\
\hline
\end{tabular}


used for preparation of medication. As aseptic measures, caps and blue nitrile gloves, but not facemasks were worn by the participants. All ampoules were swiped with $70 \%$ ethanol before opening. The outside of the ampoules was not touched by the BD blunt fill needles (BD, Oxford, United Kingdom). After each diluting step, the providers were advised to use a new needle.

There were four methods to which a participant was obliged to prepare a syringe. Method 1 was diluting 10 $\mathrm{mg} / \mathrm{ml}$ of morphine in a single step. It started with drawing up $1 \mathrm{ml}$ of $10 \mathrm{mg} / \mathrm{ml}$ morphine. This was injected in a container of $100 \mathrm{ml} \mathrm{NaCl} 0.9 \%$. Three $\mathrm{ml}$ of this mixture was aspirated into a $5 \mathrm{ml}$ syringe and 2 $\mathrm{ml}$ of $5 \mathrm{mg} / \mathrm{ml}$ bupivacaine was added. Method 2 was a double-dilution method from $10 \mathrm{mg} / \mathrm{ml}$ of morphine. It started with drawing up $1 \mathrm{ml}$ of $10 \mathrm{mg} / \mathrm{ml}$ morphine in a $10 \mathrm{ml}$ syringe. This was diluted with $9 \mathrm{ml}$ of $\mathrm{NaCl}$ $0.9 \%$ in the same syringe. After mixing, $9 \mathrm{ml}$ of this content was discarded and the remaining $1 \mathrm{ml}$ was diluted again with $9 \mathrm{ml}$ of $\mathrm{NaCl} 0.9 \%$. After mixing, $3 \mathrm{ml}$ of this mixture was aspirated in a $5 \mathrm{ml}$ syringe and $2 \mathrm{ml}$ of $5 \mathrm{mg} / \mathrm{ml}$ bupivacaine was added. Method 3 was a single dilution step of $1 \mathrm{mg} / \mathrm{ml}$ morphine. It started with aspiration of $1 \mathrm{ml}$ of $1 \mathrm{mg} / \mathrm{ml}$ morphine into a $10 \mathrm{ml}$ syringe. This was diluted with $9 \mathrm{ml}$ of $\mathrm{NaCl} 0.9 \%$. After mixing, $3 \mathrm{ml}$ of this mixture was aspirated in a $5 \mathrm{ml} \mathrm{syr-}$ inge and $2 \mathrm{ml}$ of $5 \mathrm{mg} / \mathrm{ml}$ bupivacaine was added. For group Pharmacy the aforementioned $5 \mathrm{ml}$ ready-to-use ampoule of bupivacaine and morphine was aspirated into a $5 \mathrm{ml}$ syringe.

After each prepared syringe, the participants were advised to change into new nitrile gloves. Participants could perform their tasks at their own speed. Two syringes per method were prepared, leading to a total of 8 syringes per provider. Syringes were marked after each preparation. The participants started with method 1 then method 2 and proceeded to method 3. Pharmacy group contained syringes drawn from pharmacy prepared ampoules. Per method, one syringe was analysed for drug concentration and one for bacterial contamination. No materials were re-used for method 2, 3 and pharmacy group. For method 1, two samples were taken from the same $100 \mathrm{ml} 0.9 \% \mathrm{NaCl}$-container.

After preparation, all the syringes were capped and analysed the same day in the pharmacy department for drug concentrations and bacterial contamination. The syringes were tested for concentration of morphine and bupivacaine by High-Pressure Liquid Chromatography (HPLC) at $285 \mathrm{~nm}$ in a $125 \mathrm{~mm} \mathrm{X} 4 \mathrm{~mm}$ fluid column. Testing of the microbiological culture was done with the standardized method of the pharmacy department by injecting the fluid through a filter and culturing for 7 days of the filter. The contaminating microbes were identified in positive cultures.

\section{Statistics}

A power analysis was performed with GPower 3.1. A concentration was deemed clinically acceptable if the concentration was in the range between $48 \mathrm{mcg} / \mathrm{ml}$ and $72 \mathrm{mcg} / \mathrm{ml}$ of morphine. This would be a target concentration of $80 \%$ or $120 \%$, with an assumed standard deviation of $20 \%$. We assumed that the concentration in the group "Pharmacy" would be a mean of $60 \mathrm{mcg} / \mathrm{ml}$ with a margin of error of $2 \mathrm{mcg} / \mathrm{ml}$, leading to a target concentration of $100 \%$ with a deviation of $3 \%$. In order to detect between the groups, using an alpha of 0.05 and a beta of $0.8,10$ samples per group were necessary. To increase accuracy and correct for multiple testing, 25 samples per group were obtained.

Data is described as n (\%) or as median (95\% Confidence Interval). The Chi-square-test was used for original data. Kruskal-Wallis was used for the testing of continuous data. A $p<0.005$ was considered appropriate and Bonferroni correction was applied when necessary. All testing was performed with SPSS 25.0 (IBM, Armonk, New York) and graphics were made by GraphPad Prism version 7.1 (GraphPad Software, San Diego, California).

\section{Results}

All continuous data showed a non-normal distribution (Shapiro-Wilk-test, $p<0.05$ ). The distribution of the morphine is displayed in Fig. 1. Details of morphine and bupivacaine concentrations are presented in Table 2 . Group 1 had three outliers with morphine concentrations of 189, 246 and $287 \mu \mathrm{g} / \mathrm{ml}$. Morphine concentrations were most precise in the pharmacy group $(59 \mu \mathrm{g} /$ $\mathrm{ml}$; $95 \%$ CI of $59-59 \mu \mathrm{g} / \mathrm{ml})$ followed by group $3(69 \mu \mathrm{g} /$ $\mathrm{ml} ; 95 \% \mathrm{CI}$ of $66-71 \mu \mathrm{g})$, group $2(76 \mu \mathrm{g} / \mathrm{ml} ; 95 \%$ CI of $72-80 \mu \mathrm{g} / \mathrm{ml})$ and finally group $1(60 \mu \mathrm{g} / \mathrm{ml} ; 95 \%$ CI of $59-110 \mu \mathrm{g} / \mathrm{ml})$. Groups 2 and 3 reached higher concentrations than the pharmacy group ( $p=0.000$, Fig. 1$)$.

Accuracy was calculated as the difference between the individual measurements and the target-concentration. No difference in accuracy between group 2 and 3 was detected $(16 \mu \mathrm{g}(10-22)$ [2-33] vs. $9 \mu \mathrm{g}(6-15)$ [1-28], $p=0.329)$. The pharmacy group was the most accurate $(p=0.000$ for all comparisons with groups 1,2 and 3$)$. No difference in accuracy between groups 1 and 3 was detected ( $2 \mu \mathrm{g}$ (95\% CI: $2-51)$ vs. 9 (95\% CI: $7-11 \mu \mathrm{g})$, $p=0.645)$.

Bupivacaine concentrations were not different between groups $1-3$ ( $p=1.000$ for all comparisons). Since the pharmacy group had a higher concentration, we calculated the difference between the target and the measured concentrations. Again, no difference was detected ( $p=$ 1.000 for all comparisons).

There was no relation detected between the anesthesia provider and the accuracy of the morphine concentrations $(P=0.462)$. 


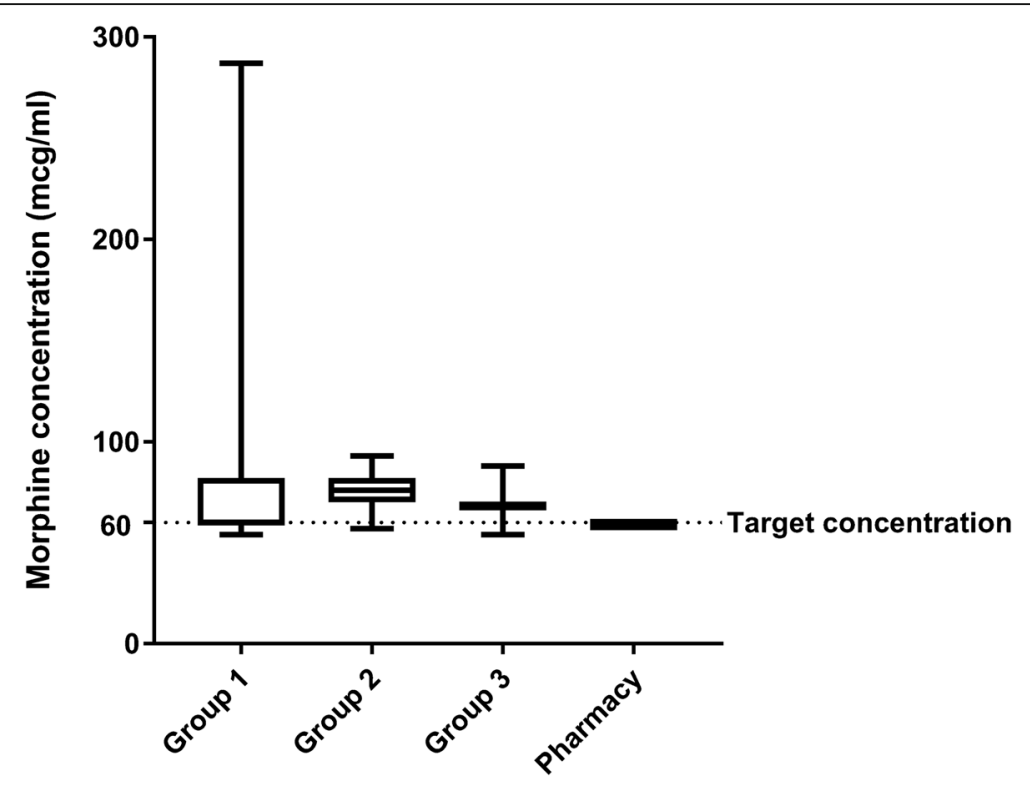

Fig. 1 Morphine concentrations. Box and whiskers demonstrate the median, interquartile range and range

Two samples had positive cultures with spore-forming aerobic gram-positive rods (group $2 \& 4)(p=1.000)$. These were prepared by the same provider. In one sample a fiber was detected (group 2).

\section{Discussion}

Our results show that diluting a medicine manually is prone to deviating concentrations, even by experienced personnel. The concentrations in the group "Pharmacy" were precise and accurate. Of the manual dilution methods, the 3rd led to most accurate and precise concentrations. This means that a lower starting concentration leads to higher precision and accuracy. Contamination occurred in groups 2 and pharmacy group.

The dilution method in group 1 resulted in three cases with concentrations which could result in respiratory depression when injected intrathecally. If five millilitres of these solutions would have been injected it would result in an injected dose of 1 to $1.5 \mathrm{mg}$ intrathecally, while the targeted dose is $300 \mu \mathrm{g}$. Therefore, this method should not be used. It illustrates that this dilution process is at risk of creating dangerously high morphine concentrations. The erroneous high concentration is possibly achieved because no new extraction needle was used and by the lack of rinsing off the first extracting needle in this protocol, thereby leaving a small volume of high concentration morphine in the needle. A second explanation may be because the solution did not mix properly in the $100 \mathrm{ml}$ container [9].

The precision of group 2 and 3 was clinically acceptable, even though the accuracy was limited. When these methods of dilution are clinically applied, one has to aim for the lower limit of the therapeutic range of intrathecal morphine to prevent an inadvertently high dose. The higher concentration is possibly caused by the excess volume of a $1.0 \mathrm{ml}$ morphine ampoule, which has to be more than $1.0 \mathrm{ml}$ to allow an extractable volume of 1.0 $\mathrm{ml}$ [12]. We believe that methods 2 and 3 are inherently

Table 2 Details of concentrations of morphine and bupivacaine

\begin{tabular}{lllll}
\hline Group & Method 1 & Method 2 & Method 3 & Pharmacy \\
\hline Morphine concentration $(\boldsymbol{\mu g} / \mathbf{m l})$ & $60(59-110)$ & $76(72-80)$ & $69(66-71)$ & $59(59-59)$ \\
Bupivacaine $(\mathbf{m g} / \mathbf{m l})$ & $1.98(1.73-2.06)$ & $2.00(1.95-2.03)$ & $1.97(1.91-2.00)$ & $2.54(2.54-2.55)$ \\
Morphine Out-of-range $(<\mathbf{8 0 \% )}$ & $0(0 \%)$ & $0(0 \%)$ & $0(0 \%)$ & $0(0 \%)$ \\
$\begin{array}{l}\text { Morphine Out-of-range }(>\mathbf{1 2 0} \%) \\
\text { Bupivacaine }\end{array}$ & $7(28 \%)$ & $18(72 \%)$ & $3(12 \%)$ & $0(0 \%)$ \\
$\begin{array}{l}\text { Out-of-Range }(<\mathbf{8 0} \%) \\
\text { Bupivacaine }\end{array}$ & $0(0 \%)$ & $0(0 \%)$ & $1(4 \%)$ & $0(0 \%)$ \\
Out-of-Range $(>\mathbf{1 2 0} \%)$ & & $1(4 \%)$ & $0(0 \%)$ & $0(0 \%)$
\end{tabular}

Data presented as median $(95 \% \mathrm{Cl})$ or $\mathrm{n}(\%)$ where appropriate 
safer methods, because the needle is rinsed if no new needle is used and the solution is mixed by aspiration of $9 \mathrm{ml}$ of saline. This is supported by the study of Benkhadra et al., which shows that mixing of the syringe results in a homogenous distribution of the solution [9]. Even though this was a relatively minor effect, every cause for imprecision should be excluded.

Most remarkably, 2 groups contained a contaminated sample, despite precautions of clean preparation, such as wearing non-sterile gloves and caps and swiping the ampoule with $70 \%$ ethanol before opening. In addition, this study was performed in the Post Anesthesia Care Unit, a room where intrathecal injections are commonly performed. We did not instruct the participants to wear face masks, because we prepared the solutions as in daily practice. Dilution steps did not appear to increase bacterial contamination. Given the rate of contamination, it is surprising that the incidence of bacterial meningitis after an intrathecal injection is around 1: 53.000 [11].

Several pathways for contamination of intrathecal injection are described. One pathway consists of bacteria originating from the oropharynx of the healthcare provider falling on the sterile area and instruments. The aerobic spores are predominantly found on skin and materials, but seldom in the human oral cavity, making it unlikely that wearing a face mask during preparation would change the results. A second pathway is that contaminated particles fall in the ampoule when this is opened $[10,13]$. Based on the identified spores, this pathway is more likely. The current study shows contaminated medication could be an important pathway of introducing a microorganism into the cerebrospinal fluid and our precautions fail to prevent contamination by this bacterium [14].

This contamination with aerobe gram-positive rods is most likely Bacillus cereus which is also part of the human skin flora and commonly associated with contamination [15]. The spores of Bacillus cereus are alcohol-resistant [16]. In healthy patients, the possibility of a Bacillus cereus infection in the central nervous system is low because of intact host resistance. In immunocompromised patients, however, Bacillus cereus was identified as causative microorganism for meningitis leading to fatal outcomes $[17,18]$. The inability to remove the spores with alcohol might pose a risk in immunocompromised patients, even though a Bacillus cereus-meningitis is rare. It is possible although difficult to remove the spores of Bacillus cereus by using disinfection procedures with solutions containing high concentration chlorine or hydrogen peroxide.

Bupivacaine was added to measure control of volume. This study showed that the aspiration of $2 \mathrm{ml}$ into a $5 \mathrm{ml}$ syringe is accurate. Furthermore, bupivacaine has antibacterial properties, making it of interest for the measurement of contamination [19]. Despite this antibacterial effect, contamination occurred in $2 \%$ of the syringes. The difference in bupivacaine concentration between group pharmacy $(2.5 \mathrm{mg} / \mathrm{ml})$ and the other groups $(2.0$ $\mathrm{mg} / \mathrm{ml}$ ) is unlikely to affect the contamination rate $[20$, 21].

A few recommendations can be made based on this study. Firstly, prefabricated drugs should be preferred in clinical practice. In some countries, dilution of medication is regarded as compounding of medication and is subject to strict regulations. If prefabricated medication is not available, one should dilute from the lowest possible starting concentration and mix the syringe during the process.

Secondly, sterile precautions should be undertaken when medication for intrathecal use is prepared, since bacterial contamination is likely to occur as shown by Zacher et al. [13] Several hospitals routinely prepare drugs with high microbiological risk, such as intrathecal administrations, in a cleanroom environment, either centrally in the hospital pharmacy or decentral in a laminar flow cabinet in close proximity to the operation theatres. Contamination occurs during dilution or aspiration of medication. Our study fails to demonstrate a lower risk of contamination with ready to use (RTU) medication. Prefilled sterile syringes, which are ready to administer (RTA) could be an alternative for (RTU) medication. Use of these prefilled syringes would avoid drawing up the medication. The effects of using prefilled sterile syringes on contamination should be investigated further.

Thirdly, clinical studies regarding intrathecal morphine sometimes do not describe the manufacturing process [22] or dilute manually [23]. Manually diluted drugs could yield a variance in dose with a different effect/side effect ratio. Therefore, the manufacturing process should be described in clinical studies.

A limitation of this study is that we did not determine the species beyond the gram-stain.

Gram positive aerobe spore forming bacteria are either Bacillus antracis or Bacillus cereus. The first would be very unlikely. Additionally, the bupivacaine concentration in the group pharmacy differed from the other groups, although this range of bupivacaine is unlikely to affect the contamination rate of Bacillus cereus [21]. Also, the incidence of contamination was not less in the pharmacy group.

\section{Conclusion}

Manual dilution of medication may lead to inaccurate concentrations. We recommend using prepared solutions from the hospital pharmacy. If these are not 
available, it is advised to use the lowest starting concentration available. In studies, the medication should be produced by the pharmacy since manual dilution can cause an erroneous dose. Contamination of medication is a serious risk and precautions should be taken seriously, even though in this study it appeared to be unrelated to the method used.

\section{Abbreviations}

mg: Milligram; $\mu$ g: Microgram; ml: Millilitre; $\mu \mathrm{m}$ : Micrometre; nm: Nanometre; HPLC: High-Pressure Liquid Chromatography; Cl: Confidence interval; GMP: Good Manufacturing Practice; BD: Becton Dickinson; RTA: Ready to administer; RTU: Ready to use

\section{Acknowledgments}

We thank the departments of anesthesiology and clinical pharmacy of the Maasstad Hospital, Rotterdam, The Netherlands for their support.

\section{Authors' contributions}

All authors have read and approved the manuscript. AT: Initiator study, corresponding author, drafting manuscript, design of study and finalization. MK: Fellow initiator, drafting manuscript and statistics. ER: Fellow initiator study and pharmaceutical foundation and backgrounds. WL: Review manuscript on pharmaceutical details and necessary pharmacy information. BB: Inclusion, instruction and coaching of anesthesia providers during study. SK: Review of manuscript and co-author for scientific adequacy.

\section{Funding}

Maasstad Pharmacy and Operating Room department delivered all material and time consumed by their employees.

\section{Availability of data and materials}

The datasets used and/or analysed during the current study are available from the corresponding author on reasonable request.

\section{Ethics approval and consent to participate}

All anesthesia providers verbally approved and consented to participate. For this study, medical ethical approval was waived by the medical ethical committee of the Maasstad Hospital (Toetsingscommissie Wetenschappelijk Onderzoek Rotterdam e.o., February 5, 2018).

\section{Consent for publication}

Not applicable.

\section{Competing interests}

None.

\section{Author details}

'Anesthesiology, Maasstadziekenhuis, Maasstadweg 21, 3079DZ Rotterdam, The Netherlands. ${ }^{2}$ Anesthesiology, Rijnstate hospital, Arnhem, The Netherlands. ${ }^{3}$ Pharmacy, Erasmus Medical Center, University of Rotterdam, Rotterdam, The Netherlands. ${ }^{4}$ Pharmacy, Maasstadziekenhuis, Rotterdam, The Netherlands.

\section{Received: 20 February 2020 Accepted: 8 September 2020}

Published online: 25 September 2020

\section{References}

1. Mugabure BB. A clinical approach to neuraxial morphine for the treatment of postoperative pain. Pain Res Treat. 2012;2012:612145.

2. Koning MV, Teunissen AJW, van der Harst E, Ruijgrok EJ, Stolker RJ. Intrathecal morphine for laparoscopic segmental colonic resection as part of an enhanced recovery protocol: a randomized controlled trial. Reg Anesth Pain Med. 2018:43:166-73.

3. Ko S, Goldstein DH, VanDenKerkhof EG. Definitions of "respiratory depression" with intrathecal morphine postoperative analgesia: a review of the literature. Can J Anaesth. 2003;50:679-88.
4. Dworzak H, Fuss F, Buttner T. Persisting respiratory depression following intrathecal administration of morphine and simultaneous sedation with midazolam. Anaesthesist. 1999;48:639-41.

5. Gehling M, Tryba M. Risks and side-effects of intrathecal morphine combined with spinal anaesthesia: a meta-analysis. Anaesthesia. 2009;64: 643-51.

6. Meylan N, Elia N, Lysakowski C, Tramer MR. Benefit and risk of intrathecal morphine without local anaesthetic in patients undergoing major surgery: meta-analysis of randomized trials. Br J Anaesth. 2009;102:156-67.

7. Toyoyama H, Mizutani K, Toyoda Y. One drop of morphine added to local anesthetics by means of a 23-gauge injection needle can relieve postoperative pain under spinal anesthesia. Anesth Analg. 2000;90:1000.

8. Baker AR, Rutherford DM, Myles PS. Accuracy of dilution of morphine for intrathecal use. Anaesth Intensive Care. 2007;35:378-81.

9. Benkhadra M, Rivory JC, Wessels C, et al. Accuracy in obtaining $100 \mu \mathrm{g}$ from $10 \mathrm{mg}$ of morphine for spinal anesthesia. J Clin Anesth. 2015;27:638-45.

10. Baer ET. Post-dural puncture bacterial meningitis. Anesthesiology. 2006;105: 381-93.

11. Moen V, Dahlgren $\mathrm{N}$, Irestedt L. Severe neurological complications after central neuraxial blockades in Sweden 1990-1999. Anesthesiology. 2004;101: 950-9.

12. Europe Council. European Pharmacopoeia. 9th ed. Strasbourg; 2015. 2.9.17 (Dosage Forms - Parenterals.).

13. Zacher AN, Zornow MH, Evans G. Drug contamination from opening glass ampules. Anesthesiology. 1991;75:893-5.

14. Videira RL, Ruiz-Neto PP, Brandao NM. Post spinal meningitis and asepsis. Acta Anaesthesiol Scand. 2002;46:639-46.

15. Bottone EJ. Bacillus cereus, a volatile human pathogen. Clin Microbiol Rev. 2010;23:382-98.

16. Dolan SA, Littlehorn C, Glode MP, et al. Association of Bacillus cereus infection with contaminated alcohol prep pads. Infect Control Hosp Epidemiol. 2012;33:666-71.

17. Tusgul S, Prod'hom G, Senn L, Meuli R, Bochud PY, Giulieri SG. Bacillus cereus bacteraemia: comparison between haematologic and nonhaematologic patients. New Microbes New Infect. 2017;15:65-71.

18. Stevens MP, Elam K, Bearman G. Meningitis due to Bacillus cereus: a case report and review of the literature. Can J Infect Dis Med Microbiol. 2012;23: e16-9.

19. Adler DMT, Damborg P, Verwilghen DR. The antimicrobial activity of bupivacaine, lidocaine and mepivacaine against equine pathogens: an investigation of 40 bacterial isolates. Vet J. 2017;223:27-31.

20. Sakuragi T, Ishino H, Dan K. Bactericidal activity of clinically used local anesthetics on Staphylococcus aureus. Reg Anesth. 1996;21:239-42.

21. Rosenberg PH, Renkonen OV. Antimicrobial activity of bupivacaine and morphine. Anesthesiology. 1985;62:178-9.

22. Bae J, Kim HC, Hong DM. Intrathecal morphine following robot-assisted prostatectomy: a prospective randomised trial. J Anesth. 2017;31(4):565-71.

23. Vasudevan A, Snowman CE, Sundar S, Sarge TW, Hess PE. Intrathecal morphine reduces breakthrough pain during labour epidural analgesia. Br J Anaesth. 2007;98(2):241-5.

\section{Publisher's Note}

Springer Nature remains neutral with regard to jurisdictional claims in published maps and institutional affiliations.
Ready to submit your research? Choose BMC and benefit from:
- fast, convenient online submission
- thorough peer review by experienced researchers in your field
- rapid publication on acceptance
- support for research data, including large and complex data types
- gold Open Access which fosters wider collaboration and increased citations
- maximum visibility for your research: over $100 \mathrm{M}$ website views per year
At $\mathrm{BMC}$, research is always in progress.
Learn more biomedcentral.com/submissions 